\title{
The Involvement of Type 2 Innate Lymphoid Cells in Airway Inflammation of Asthma
}

\author{
Ruiming Shi, Xuhua Bian, Shuang Feng, Xiaoxia Yang, Tao Zhao, and Min Guo
}

The airway inflammatory response is closely associated with asthma. The purpose of this article was to study the roles of innate lymphoid cells (ILCs) in the process of airway inflammatory response in asthma. We established the asthmatic mice model with intraperitoneal injected ovalbumin medium, then with the flow cytometry analysis, we detected the ILCs and their surface proteins in the mice blood samples, besides, we analyzed the amounts of inflammatory cytokines and secreted proteins in the mice bronchoalveolar lavage fluid and blood serum. Moreover, Western blot analyzed the proteins in the mice bronchial epithelial tissues. The ILC2 amounts were obviously increased in young asthmatic mice model. And, the proteins CD25 and CCR10 were highly expressed in the sorted ILC2s. Besides, the cytokines interleukin (IL)-5, IL-13, IL-33, CCL22, and CCL27 were abundant in the bronchoalveolar lavage fluid of asthmatic mice model. And, the secretion of IL-5, IL-13, IL-33, TSLP, and CCL22 in blood serum was much more in asthmatic mice model than in the normal control mice, whereas the secretion of PGD2 was suppressed in asthmatic mice bronchoalveolar lavage fluid

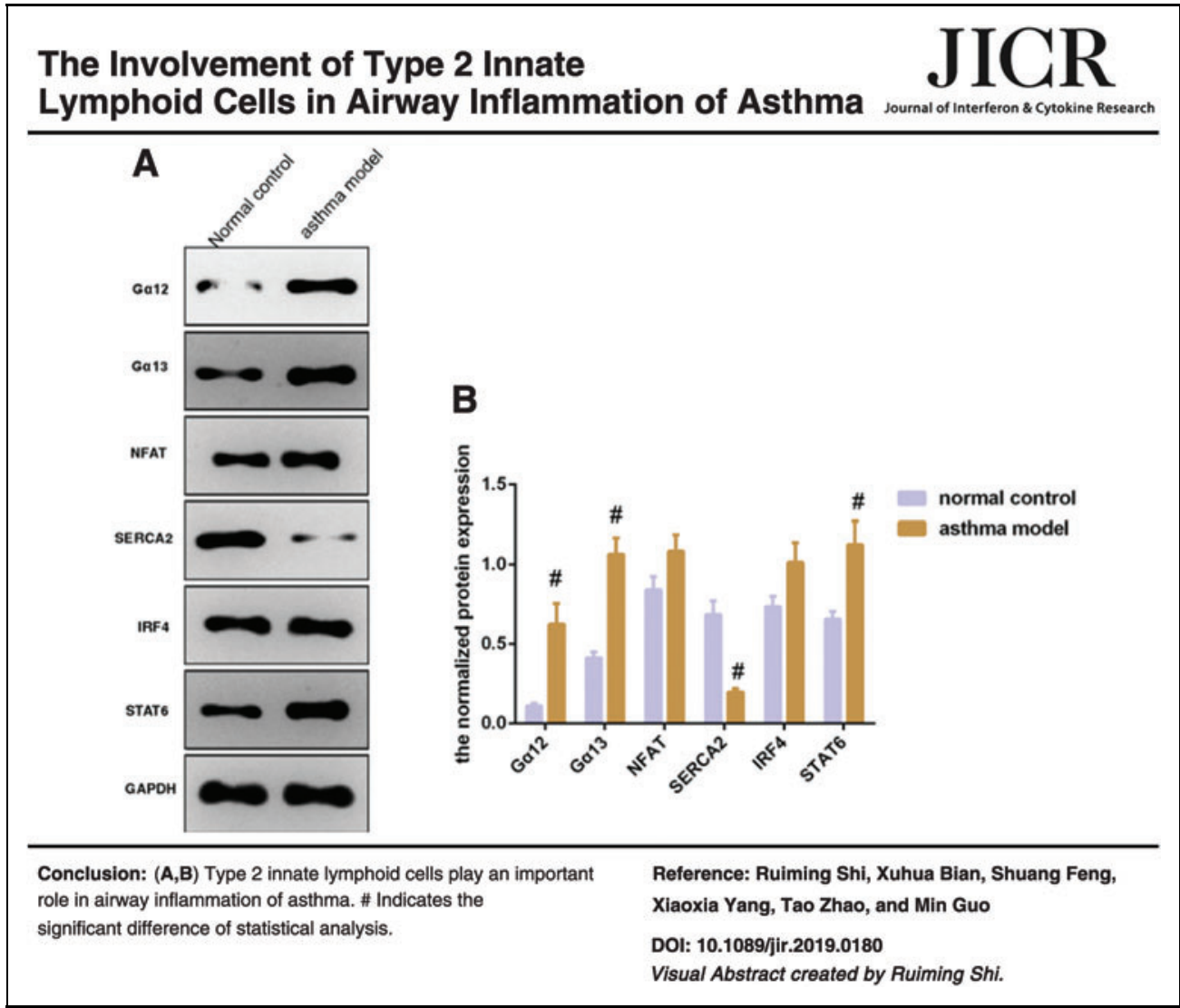

Color images are available online.

Department of Pediatrics, The First Affiliated Hospital of Xi'an Jiaotong University, Xi'an, China. 
and blood serum. Additionally, the guanine nucleotide-binding proteins $G \alpha 12$ and $G \alpha 13$ were upregulated in asthmatic mice bronchial tissues, and the protein SERCA2 was downregulated; moreover, the proteins NFAT, IRF4, and its downstream signal STAT6 were all upregulated in the asthmatic mice bronchial tissues. ILC2s were involved in the response of airway inflammation through secretion of proinflammatory cytokines and chemokines to dysregulate the $\mathrm{Ca}^{2+}$ homeostasis in airway in the process of asthma.

Keywords: ILC2s, airway inflammation, $\mathrm{Ca}^{2+}$ homeostasis, asthma

\section{Introduction}

A STHMA IS A kind of disease with airway hyperresponsiveness (AHR) and airway inflammatory response (Haselkorn and others 2009; Pulendran and Artis 2012). Studies had showed that T lymphocytes and innate lymphocytes contributed greatly to the exacerbation of asthma (Peebles and Aronica 2019). For example, Th1 cells (Hayashi and others 2007) were proved to secret interleukin (IL)-13 and interferon- $\gamma$ (IFN- $\gamma$ ), Th2 cells (Halim and others 2012) were identified to produce IL-4, IL-5, and IL-13, and Th17 (Halwani and others 2017) cells were involved in releasing IL-17A and IL-17F. Moreover, the innate type 2 immune cells were also found in the blood of asthmatic patients (Bartemes and others 2014).

Innate lymphoid cells (ILCs) had been gradually recognized since 2008 and 2009 (Vivier and others 2016); they played important roles in regulating immune homeostasis, inflammatory response, and microenvironment homeostasis (Artis and Spits 2015). The ILC1 populations were a lineage of classical NK cells secreting IFN- $\gamma$ to anti-inflammation and antibacterial (Seillet and Belz 2016), whereas the functions of ILC3 population were similar to Th17 and Th22 cells, which were mainly located in intestinal mucosa (Aparicio-Domingo and others 2015). Moreover, the ILC2 subtypes played pivotal roles in parasitic infection, allergy, and asthma (Yang and others 2016); the study by Sui and others (2018) declared that ILC2 was initiated with the alarmins IL-25, IL-33 (Anderson and others 2016; Dahlgren and others 2019); moreover, the activated ILC2s were identified to initiate the Th2 cell to co-regulate the airway inflammation (Cosmi and others 2017; Kubo 2017; Lombardi and others 2016).

The pathogenesis of asthma was closely associated with airway smooth muscle (ASM) constriction, airway epithelial cell proliferation, gland hypertrophy, and secretion of proinflammatory cytokines and chemokines (Sharma and others 2014; Peebles and Aronica 2019). Commonly, in the process of asthma, the influxed $\mathrm{Ca}^{2+}$ binded with the calmodulin to activate MLCK14 and phosphatase calcineurin, which thus activated the transcriptional factor, nuclear factor of activated T cell (NFAT), to mediate its downstream signals to implicate in inflammation (Sharma and others 2014). Besides, the sarcoendoplasmic $\mathrm{Ca}^{+}$ATPases (SERCAs) in mitochondria (Berridge and Morré 2008) were involved in the activities of intracellular influxed $\mathrm{Ca}^{2+}$. And, the study by Sathish and others (2009) clearly identified that the proinflammatory cytokines affected the sarcoplasmic reticulum $\mathrm{Ca}^{2+}$ reuptake in human ASM. Therefore, in this study, we attempted to investigate the roles of ILCs in asthma.

\section{Materials and Methods}

\section{Asthma mice model establishment}

Twenty-four Balb/c mice (female and male), 4 weeks old, 20-23 g, were brought from Animal Laboratory Center of Medical College of Xi'an Jiaotong University; they were cultivated at $20^{\circ} \mathrm{C}-25^{\circ} \mathrm{C}, 40 \%-70 \%$ relative humidity environment with a $12 \mathrm{~h}$ light/dark cycle for 1 week adaption in animal experimental research center of Medical College of Xi'an Jiaotong University, besides, the mice had free access to regular chow diet. Then, they were equally divided into 2 groups: 1 group of mice separately received $0.2 \mathrm{~mL}$ ovalbumin (OVA) medium (Sigma) with intraperitoneal injection at the first day and the 14th day, whereas the control mice were given equal vehicle administration. At the 21 day, the model mice were put in atomizing chamber and they received 5\% OVA aerosol inhalation for 7 days, $30 \mathrm{~min}$ once. After 7 days dealt with, we evaluated the mice respiratory status, activity, abdominal cramps status, and airway hyperreactivity (AHR) to confirm the model construct well (Kim and others 2019). Besides, the control mice were given phosphate-buffered saline (PBS) inhalation for 7 days, 30 min once. Thereafter, the mice were anesthetized with $2 \%$ isoflurane and sacrificed. Then, the blood was collected from the mice eyeball and aorta abdominalis, besides, the mice bronchoalveolar lavage fluid in the lung was collected and the mice bronchial tissues were obtained and snapfrozen in liquid nitrogen.

\section{Flow cytometry}

The blood samples were centrifugated at 3,500 rpm for 15 min to obtain the blood serum, and then, the lymphocytes were obtained with Ficoll density gradient centrifugation (Haoyang TBD Bio, China) from the blood serum and they were resuspended in PBS. Afterward, the lymphocytes were fixed, permeabilized, and dividedly labeled with allophycocyanin conjugation anti-mouse ILC lineage-antibody (no. 558074; BD Pharmingen ${ }^{\mathrm{TM}}$ ), the phycoerythrin-cyanine 7 (PE-Cy7)-conjugated anti-mouse CD45 antibody (no. 560696; BD Pharmingen), the PE-conjugated anti-mouse CD127 antibody (no. 552543; BD Pharmingen), the PerCPCy ${ }^{\mathrm{TM}}$ 5.5-conjugated anti-mouse CD117 antibody (no. 560557; BD Pharmingen), the Alexa Fluor ${ }^{\circledR}$ 647-conjugated antimouse CRTH2 antibody (no. 51-2941-82; Invitrogen), and the PE-conjugated anti-mouse CD161 antibody (no. 566323; BD Pharmingen) to sort out the cells, ILC1, ILC2, and ILC3 with Calibur FACS (BD) instrument. Besides, the expression of CD25 and C-C chemokine receptor type 10 (CCR10) in the selected ILC2s was also assessed with flow cytometry. And, the anti-mouse CCR10 antibody was detected with a secondary goat anti-mouse antibody labeled with fluorescein 
isothiocyanate (FITC; R\&D Systems), and the FITC-labeled anti-mouse CD25 antibody (no. 101907; BioLegend) was also analyzed in the blood samples.

\section{Enzyme-linked immunosorbent assay}

The blood samples were centrifugated at $3,500 \mathrm{rpm}$ for 10 min to obtain the blood serum, and then, the blood serum and the collected bronchoalveolar lavage fluid were dividedly analyzed with enzyme-linked immunosorbent assay (ELISA) kits following the manufacturer's instruction to quantify the concentration of IL-5 (no. 70-EK205-96; Multi Science, China), IL-13 (no. 70-EK213/2-96; Multi Science), IL-33 (no. 70-EK233/2-96; Multi Science), TSLP (no. 70EK265/2-24; Multi Science), PGD2 (no. BH8635; BOYAO, China), CCL22 (no. 70-EK2216/2-24; Multi Science), and CCL27 (no. MU30929; Bioswamp, China) in triplicates.

\section{Western blot}

The total proteins were extracted from the mice isolated bronchial tissues with radioimmunoprecipitation assay buffer containing protease inhibitors phenylmethanesulfonyl fluoride, and then, the proteins were denatured and the concentration was analyzed. Later, $20 \mu \mathrm{g}$ of proteins was added in each hole lane to separate them with sodium dodecyl sulfate-polyacrylamide gels; afterward, the gels were transferred to polyvinylidene fluoride membranes, and then, the transferred membranes were blocked with $5 \%$ fat-free milk for $1 \mathrm{~h}$. Then, the membranes were dividedly incubated with primary antibodies, anti-NFAT (no. ab2722; Abcam, UK), anti-SERCA2 (no. ab2817; Abcam), anti-guanine nucleotide-binding protein subunit alpha-12 (G $\alpha 12$, no. ab35016; Abcam), anti-G $\alpha 13$ (no. ab128900; Abcam), antiinterferon regulatory factor 4 (IRF4, no. 15106; CST), and anti-signal transducer and activator of transcription 6 (STAT6, no. 9362; CST) for 1 night, and then, the antimouse IgG antibody immunoblotted the membranes for $1 \mathrm{~h}$, besides, the glyceraldehyde 3-phosphate dehydrogenase was used as a control. Finally, the protein bands were visualized in bandscan with chemiluminescence detection reagents added and analyzed the proteins' gray intensity with the ImageJ Software.

\section{Statistical analysis}

The data were analyzed in SPSS 19.0 software with oneway analysis of variance (ANOVA), and the significant differences among groups were $P<0.05$, besides, the graphs represented the mean \pm standard deviation.

\section{Results}

\section{Type 2 ILCs contributed greatly to the response of asthmatic airway inflammation}

In the asthmatic mice model, we found that the amounts of $\mathrm{CD} 45^{+} \mathrm{CD} 127^{+}$-labeled cells were much more in the blood than in the normal control mice (Fig. 1A-D), besides, the percentage of sorted ILC1s (CD117 ${ }^{-} \mathrm{CRTH} 2^{-}$cells), ILC2s $\left(\mathrm{CD} 161^{+} \mathrm{CRTH}^{+}\right.$cells), and ILC3s $\left(\mathrm{CD} 117^{+} \mathrm{CRTH} 2^{-}\right.$ cells) was also higher than the normal control mice (Fig. 1E-G), whereas the percentage of ILC2s increased significantly compared with ILC1s and ILC3s $(P<0.05$; Fig. 1F). In ad- dition, the expression of proteins CD25 and CCR10 in the sorted ILC2s was highly expressed compared with the normal control mice (Fig. 2A-C), and the difference of CCR10 was significant $(P<0.05$; Fig. $2 \mathrm{C})$. In addition, the cytokines IL-5, IL-13, IL-33, TSLP, CCL22, and CCL27 were increased in bronchoalveolar lavage fluid and blood serum of asthmatic mice model, whereas the secretion of PGD2 was suppressed in bronchoalveolar lavage fluid and blood serum of asthmatic mice model (Fig. 3A, B). And, the differences of IL-5, IL-13, IL-33, CCL22, and CCL27 in the bronchoalveolar lavage fluid were of significance $(P<0.05$; Fig. 3A), whereas the secretion of IL-5, IL-13, IL-33, TSLP, and CCL22 in blood serum was with significant difference compared with the normal control mice $(P<0.05$; Fig. 3B). Therefore, the type 2 ILCs were the main participant in the response of asthmatic airway inflammation.

\section{Changed the expression of proteins associated with airway $\mathrm{Ca}^{2+}$ homeostasis and inflammatory response}

To determine the mechanism of asthma in mice model, we detected the expression of proteins $\mathrm{G} \alpha 12, \mathrm{G} \alpha 13$, NFAT, SERCA2, IRF4, and STAT6 in mice bronchial tissues. Results showed that the guanine nucleotide-binding proteins $\mathrm{G} \alpha 12$ and $\mathrm{G} \alpha 13$ of bronchial epithelial cellular membrane protein were upregulated in asthmatic mice bronchial tissues, besides, the expression of protein SERCA2 was suppressed to induce the inflammation and initiated unfolded protein response of endoplasmic reticulum, which thus disrupted the $\mathrm{Ca}^{2+}$ homeostasis in ASM. Moreover, the transcription factor NFAT and the transcriptional activator IRF4 along with its downstream signal STAT6 were all upregulated in the asthmatic mice bronchial tissues, besides, the proteins NFAT, IRF4, and STAT6 were immune response elements in the airway inflammation; the differences are displayed in Fig. 4.

\section{Discussion}

Asthma is a disease that seriously challenged public health, especially in young children and the old (Honkamaki and others 2019). In this study, results showed that ILC2s were the major immune regulator in the pathogenesis of asthma. And, the proteins CCR10 and CD25 were highly expressed in the ILC2 cells. The protein CCR10 is a receptor of CCL27, which was a great potential biomarker of ILC2s and contributed to asthma severity (Beuraud and others 2019), whereas the protein CD25 was also a membrane protein of lineage-marker negative ILC2s in asthmatic mice lung (Klein Wolterink and others 2012). Besides, the study by Roan and others (2012) declared that the functions of ILC2s were similar with TH2 cells. Hence, there is possibility that ILC2s involved in the inflammation of IL-4, IL-5, and IL-13 cytokines secreted by Th2 cells (Woodruff and others 2009). Meanwhile, in our study of the blood and bronchoalveolar lavage fluid samples, we found that the cytokines IL-5, IL-13, and IL-33 and the chemokines CCL22 and CCL27 were all significantly increased, whereas the secretion of proteins TSLP and PGD2 varied in small levels. Studies showed that there were cross talks among the secreted cytokines, chemokines, and proteins, for example, the secreted TSLP by epithelial cells could mediate the Th2 
A
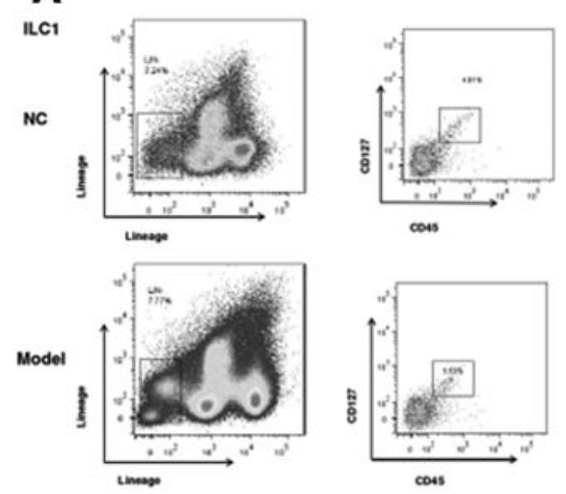

C
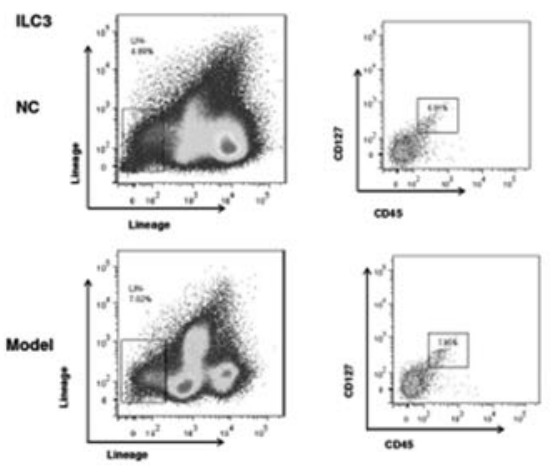

E



G

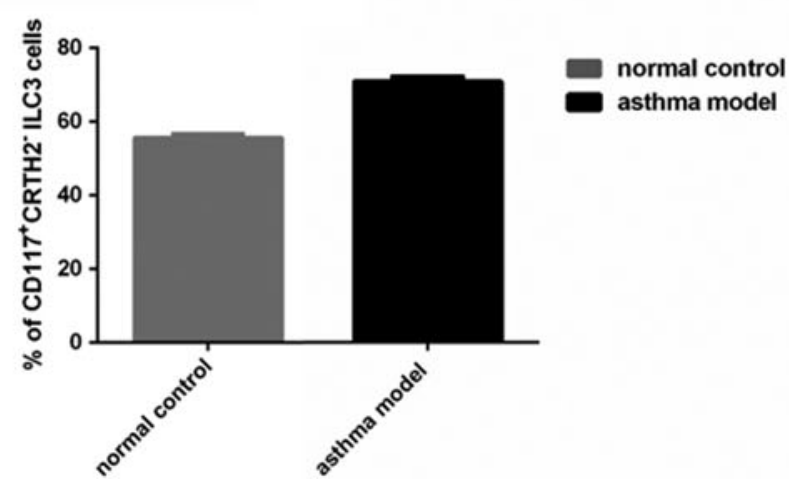

B
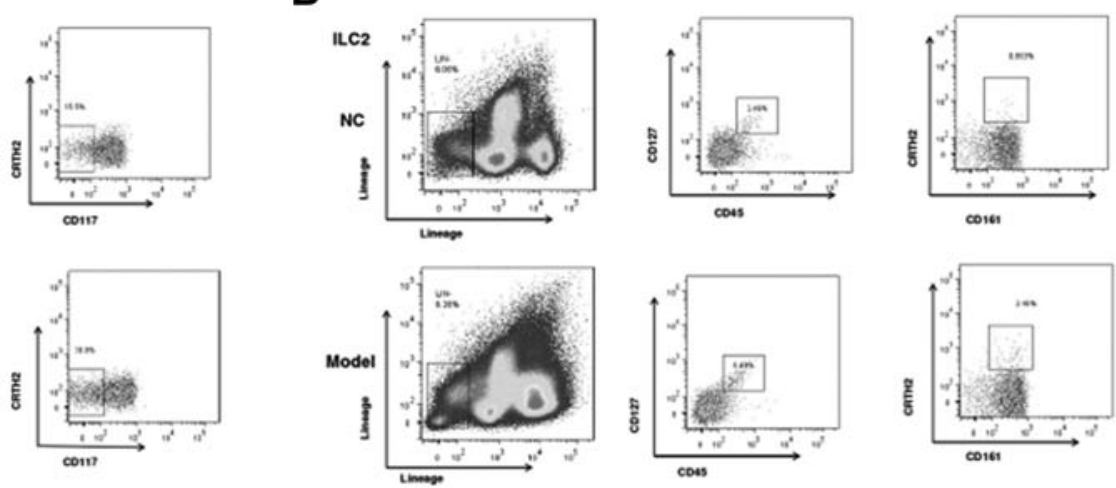

D
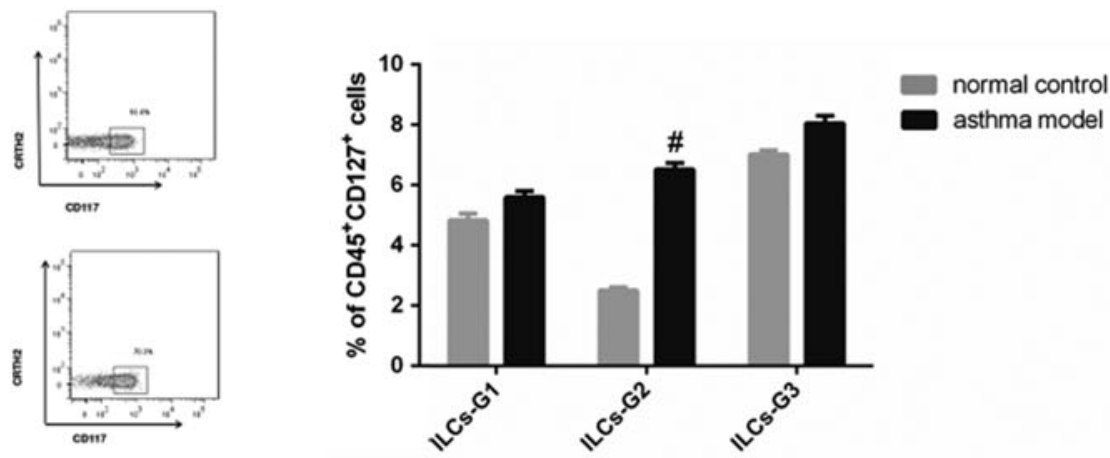

$\mathbf{F}$

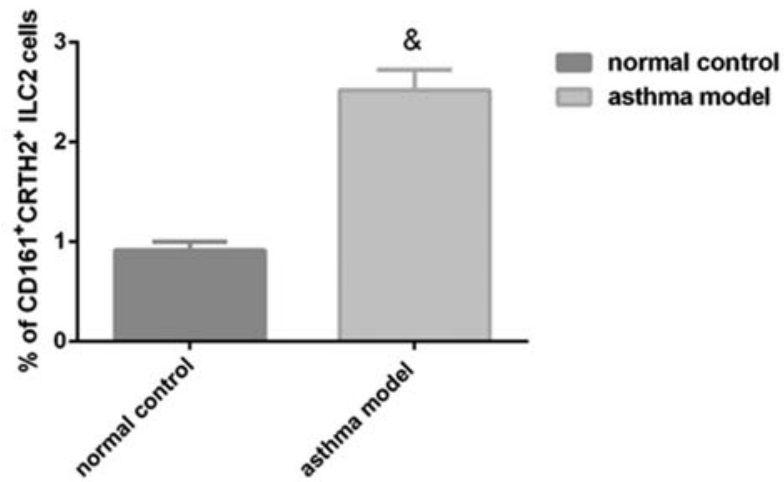

FIG. 1. ILC1s, ILC2s, and ILC3s were isolated with flow cytometry (A-C). The sorted out total ILCs (\% of $\mathrm{CD} 45^{+} \mathrm{CD} 127^{+}$cells), ${ }^{\#} P<0.05$, the significant difference of total ILCs in group 2 blood samples of asthma mice model compared with the normal control mice (D). The sorted out ILC1s (\% of CD117 ${ }^{-} \mathrm{CRTH} 2^{-}$cells) (E). The sorted out ILC2s (\% of CD161 ${ }^{+} \mathrm{CRTH} 2^{+}$cells), ${ }^{\&} P<0.05$, the significant difference of total ILC2s in group 2 blood samples of asthma mice model compared with the normal control mice (F). The sorted out ILC3s (\% of CD117 ${ }^{+} \mathrm{CRTH} 2^{-}$cells) (G). ILC, innate lymphoid cell. 


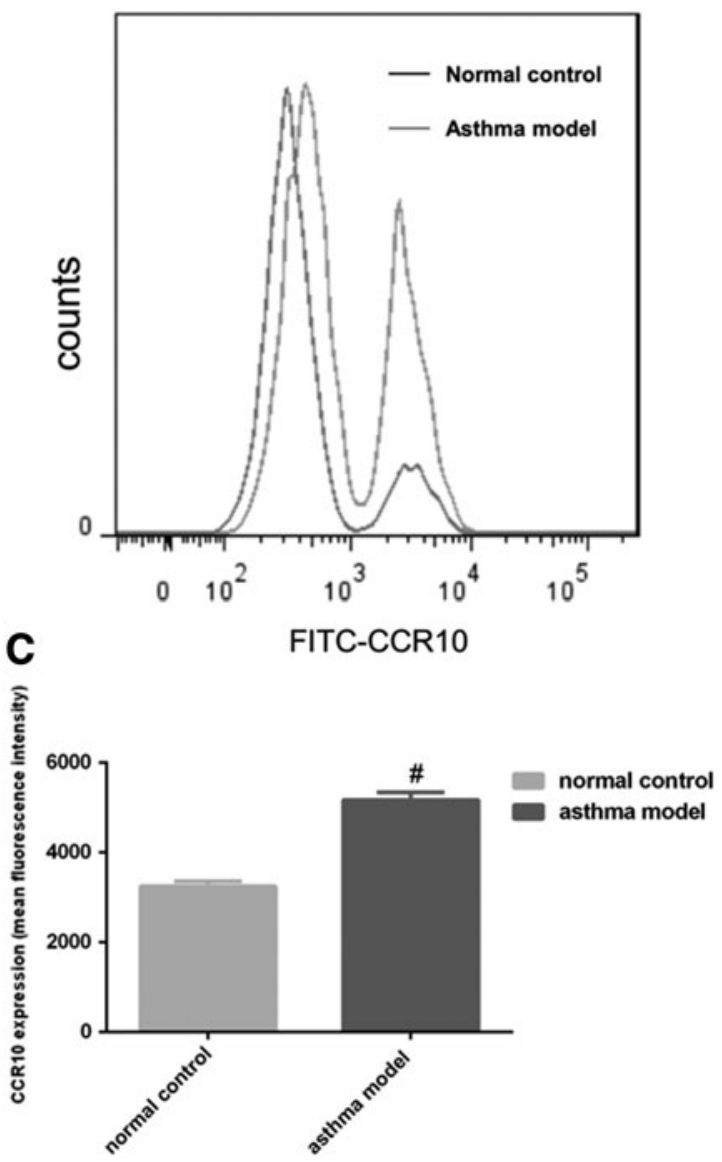

FIG. 2. The expression of CD25 and CCR10 in the selected ILC2s was assessed with flow cytometry (A), the fluorescence-labeled positive in the sorted ILC2s represented the expression of CD25 and CCR10 (B, C), the expression of CCR10 (the mean fluorescence intensity) in the asthma mice model was significantly higher than the normal control mice, ${ }^{\#} P<0.05$.

responses (Xue and others 2014), whereas the PGD2 could bind with $\mathrm{CRTH} 2$ to induce ILC2-producing chemotaxis after stimulated with IL-25 and IL-33 (Rochman and others 2018). Additionally, the activated epithelial cells could release alarmins IL-25, IL-33, or TSLP to induce ILC2secreting cytokines IL-4, IL-5, IL-9, and IL-13, which thus caused ASM cell contraction (Anderson and others 2016; Dahlgren and others 2019). Hence, the cytokines IL-5, IL-
13, IL-33, the chemokines CCL22 and CCL27, and the secreted proteins TSLP and PGD2 contributed greatly to the exacerbation of asthma.

To detect the functional change of airway epithelial cells and ASM cells in asthma, we analyzed the proteins in asthmatic mice bronchial tissues. The Western blot results showed that the guanine nucleotide-binding proteins $\mathrm{G} \alpha 12$ and $\mathrm{G} \alpha 13$ were upregulated in the mice bronchial tissue samples,
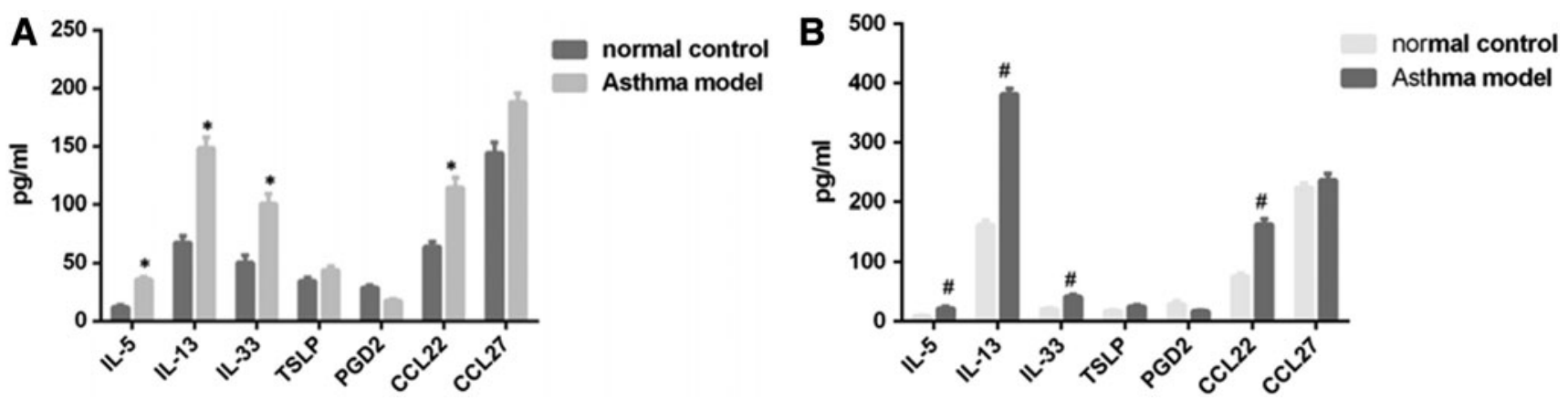

FIG. 3. ELISA analyzed the cytokines and chemokines IL-5, IL-13, IL-33, TSLP, PGD2, CCL22, and CCL27 in the bronchoalveolar lavage fluid (A) and in the blood serum (B), the levels of IL-5, IL-13, IL-33, TSLP, CCL22, and CCL27 were increased in asthma mice, ${ }^{*}{ }^{\#} P<0.05$, the significant difference of the cytokines and chemokines in the bronchoalveolar lavage fluid and in the blood serum of asthma mice compared with the normal control mice. ELISA, enzymelinked immunosorbent assay; IL, interleukin. 




FIG. 4. Western blot analyzed the expression of proteins $\mathrm{G} \alpha 12, \mathrm{G} \alpha 13$, NFAT, SERCA2, IRF4, and STAT6 in the mice bronchia tissues (A), the proteins $\mathrm{G} \alpha 12, \mathrm{G} \alpha 13$, NFAT, IRF4, and STAT6 were upregulated in asthma mice bronchia tissues, whereas the protein SERCA2 was downregulated, ${ }^{\#} P<0.05$, the significant difference of proteins expression in asthma mice model compared with the normal control mice $(\mathbf{B})$.

whereas the SERCAs protein was downregulated. The proteins $\mathrm{G} \alpha 12$ and $\mathrm{G} \alpha 13$ were responsible for the $\mathrm{Ca}^{2+}$ fluxion in the cytosol through the G-protein coupled receptor, whereas the protein SERCAs in mitochondria controlled the influx of $\mathrm{Ca}^{2+}$. These findings were consistent with the study by Sathish and others (2009). In addition, the transcription factor NFAT, IRF4, and its downstream signal STAT6 were all upregulated in the asthmatic mice, all of which were inflammatory response elements. Hence, there is potential that the airway inflammation disrupted the airway $\mathrm{Ca}^{2+}$ homeostasis activities (Halayko and others 2003; Mahn and others 2009). However, we had not clearly revealed the direct communications between them. However, Rochman and others (2018) pointed out that TSLP activated the transcription factor STAT5 through the kinase JAK2 and repressed the transcription factor BCL6 to mediate Th2 cell response in asthma. Moreover, a study by Nolin and others (2019) systematically depicted that not only the inflammatory cytokines, chemokines, and lipid mediators affected the ILC2 activity in asthma but the other factors, including the hormones, growth factors, complement peptides, neuropeptides, and neurotransmitters, also shaped the functions of ILC2 in asthma. Hence, further studies are necessary to illuminate the cross talks of asthmatic airway inflammation and the $\mathrm{Ca}^{2+}$ homeostasis activities in asthmatic airway. Taken together, ILC2s were mainly involved in the pathogenesis of asthma.

\section{Conclusion}

The type 2 ILCs were the major inflammatory regulator in the response of airway inflammation and the disruption of $\mathrm{Ca}^{2+}$ homeostasis in ASM cell in the process of asthma.

\section{Ethical Approval}

This study was accorded with the ethics of animals.

\section{Author Disclosure Statement}

No competing financial interests exist.

\section{Funding Information}

The study was funded by Shanxi Provincial Programs for Science and Technology Development (2016SF-031).

\section{References}

Anderson MD, Aitchison B, Johnson DC. 2016. Corrosion resistance of atomic layer deposition-generated amorphous thin films. ACS Appl Mater Interfaces 8(44):30644-30648.

Aparicio-Domingo P, Romera-Hernandez M, Karrich JJ, Cornelissen F, Papazian N, Lindenbergh-Kortleve DJ, Butler JA, Boon L, Coles MC, Samsom JN, Cupedo T. 2015. Type 3 innate lymphoid cells maintain intestinal epithelial stem cells after tissue damage. J Exp Med 212(11):1783-1791. 
Artis D, Spits H. 2015. The biology of innate lymphoid cells. Nature 517(7534):293-301.

Bartemes KR, Kephart GM, Fox SJ, Kita H. 2014. Enhanced innate type 2 immune response in peripheral blood from patients with asthma. J Allergy Clin Immunol 134(3):671-678.

Berridge MV, Morré DJ. 2008. Plasma membrane redox and cancer drug development. Preface. Biofactors 34(3):181-182.

Beuraud C, Lombardi V, Luce S, Horiot S, Naline E, Neukirch C, Airouche S, Perchet T, Golub R, Devillier P, CholletMartin S, Baron-Bodo V, Nony E, Aubier M, Mascarell L, Moingeon P. 2019. CCR10(+) ILC2s with ILC1-like properties exhibit a protective function in severe allergic asthma. Allergy 74(5):933-943.

Cosmi L, Liotta F, Maggi L, Annunziato F. 2017. Role of type 2 innate lymphoid cells in allergic diseases. Curr Allergy Asthma Rep 17(10):66.

Dahlgren MW, Jones SW, Cautivo KM, Dubinin A, OrtizCarpena JF, Farhat S, Yu KS, Lee K, Wang C, Molofsky AV, Tward AD, Krummel MF, Peng T, Molofsky AB. 2019. Adventitial stromal cells define group 2 innate lymphoid cell tissue niches. Immunity 50(3):707.e6-722.e6.

Halayko AJ, Amrani Y. 2003. Mechanisms of inflammationmediated airway smooth muscle plasticity and airways remodeling in asthma. Respir Physiol Neurobiol 137(2):209-222.

Halim TY, Krauss RH, Sun AC, Takei F. 2012. Lung natural helper cells are a critical source of Th2 cell-type cytokines in protease allergen-induced airway inflammation. Immunity 36(3):451-463.

Halwani R, Sultana A, Vazquez-Tello A, Jamhawi A, Al-Masri AA, Al-Muhsen S. 2017. Th-17 regulatory cytokines IL-21, IL-23, and IL-6 enhance neutrophil production of IL-17 cytokines during asthma. J Asthma 54(9):893-904.

Haselkorn T, Zeiger RS, Chipps BE, Mink DR, Szefler SJ, Simons FE, Massanari M, Fish JE. 2009. Recent asthma exacerbations predict future exacerbations in children with severe or difficult-to-treat asthma. J Allergy Clin Immunol 124(5):921-927.

Hayashi N, Yoshimoto T, Izuhara K, Matsui K, Tanaka T, Nakanishi K. 2007. T helper 1 cells stimulated with ovalbumin and IL-18 induce airway hyperresponsiveness and lung fibrosis by IFN-gamma and IL-13 production. Proc Natl Acad Sci U S A 104(37):14765-14770.

Honkamaki J, Hisinger-Molkanen H, Ilmarinen P, Piirila P, Tuomisto LE, Andersen H, Huhtala H, Sovijarvi A, Backman H, Lundback B, Ronmark E, Lehtimaki L, Kankaanranta H. 2019. Age- and gender-specific incidence of new asthma diagnosis from childhood to late adulthood. Respir Med 154:56-62.

Kim BG, Park MK, Lee PH, Lee SH, Hong J, Aung MMM, Moe KT, Han NY, Jang AS. 2019. Effects of nanoparticles on neuroinflammation in a mouse model of asthma. Respir Physiol Neurobiol 271:103292.

Klein Wolterink RG, Kleinjan A, van Nimwegen M, Bergen I, de Bruijn M, Levani Y, Hendriks RW. 2012. Pulmonary innate lymphoid cells are major producers of IL-5 and IL-13 in murine models of allergic asthma. Eur J Immunol 42(5): 1106-1116.

Kubo M. 2017. Innate and adaptive type 2 immunity in lung allergic inflammation. Immunol Rev 278(1):162-172.

Lombardi V, Beuraud C, Neukirch C, Moussu H, Morizur L, Horiot S, Luce S, Wambre E, Linsley P, Chollet-Martin S, Baron-Bodo V, Aubier M, Moingeon P. 2016. Circulating innate lymphoid cells are differentially regulated in allergic and nonallergic subjects. J Allergy Clin Immunol 138(1):305-308.

Mahn K, Hirsta SJ, Ying S, Holt MR, Lavender P, Ojo OO, Siew L, Simcock DE, McVicker CG, Kanabar V, Snetkov VA,
O'Connor BJ, Karner C, Cousins DJ, Macedo P, Chung KF, Corrigan CJ, Ward JPT, Lee TH. 2009. Diminished sarco/endoplasmic reticulum $\mathrm{Ca}^{+}$ATPase (SERCA) expression contributes to airway remodelling in bronchial asthma. PNAS 106(26):10775-10780.

Nolin JD, Murphy RC, Gelb MH, Altemeier WA, Henderson WR, Jr., Hallstrand TS. 2019. Function of secreted phospholipase A2 group-X in asthma and allergic disease. Biochim Biophys Acta Mol Cell Biol Lipids 1864(6):827-837.

Peebles RS, Jr., Aronica MA. 2019. Proinflammatory pathways in the pathogenesis of asthma. Clin Chest Med 40(1):29-50.

Pulendran B, Artis D. 2012. New paradigms in type 2 immunity. Science 337(6093):431-435.

Roan F, Bell BD, Stoklasek TA, Kitajima M, Han H, Ziegler SF. 2012. The multiple facets of thymic stromal lymphopoietin (TSLP) during allergic inflammation and beyond. J Leukoc Biol 91(6):877-886.

Rochman Y, Dienger-Stambaugh K, Richgels PK, Lewkowich IP, Kartashov AV, Barski A, Khurana Hershey GK, Leonard WJ, Singh H. 2018. TSLP signaling in CD4(+) T cells programs a pathogenic $\mathrm{T}$ helper 2 cell state. Sci Signal 11(521): eaam8858.

Sathish V, Thompson MA, Bailey JP, Pabelick CM, Prakash YS, Sieck GC. 2009. Effect of proinflammatory cytokines on regulation of sarcoplasmic reticulum $\mathrm{Ca} 2+$ reuptake in human airway smooth muscle. Am J Physiol Lung Cell Mol Physiol 297(1):L26-L34.

Seillet C, Belz GT. 2016. Differentiation and diversity of subsets in group 1 innate lymphoid cells. Int Immunol 28(1):3-11.

Sharma P, Basu S, Mitchell RW, Stelmack GL, Anderson JE, Halayko AJ. 2014. Role of dystrophin in airway smooth muscle phenotype, contraction and lung function. PLoS One 9(7):e102737.

Sui P, Wiesner DL, Xu J, Zhang Y, Lee J, Van Dyken S, Lashua A, Yu C, Klein BS, Locksley RM, Deutsch G, Sun X. 2018. Pulmonary neuroendocrine cells amplify allergic asthma responses. Science 360(6393): eaan8546.

Vivier E, van de Pavert SA, Cooper MD, Belz GT. 2016. The evolution of innate lymphoid cells. Nat Immunol 17(7):790-794.

Woodruff PG, Modrek B, Choy DF, Jia G, Abbas AR, Ellwanger A, Koth LL, Arron JR, Fahy JV. 2009. T-helper type 2-driven inflammation defines major subphenotypes of asthma. American journal of respiratory and critical care medicine 180(5):388-395.

Xue L, Salimi M, Panse I, Mjosberg JM, McKenzie AN, Spits H, Klenerman P, Ogg G. 2014. Prostaglandin D2 activates group 2 innate lymphoid cells through chemoattractant receptor-homologous molecule expressed on $\mathrm{TH} 2$ cells. J Allergy Clin Immunol 133(4):1184-1194.

Yang Q, Ge MQ, Kokalari B, Redai IG, Wang X, Kemeny DM, Bhandoola A, Haczku A. 2016. Group 2 innate lymphoid cells mediate ozone-induced airway inflammation and hyperresponsiveness in mice. J Allergy Clin Immunol 137(2):571-578.

Address correspondence to: Dr. Ruiming Shi

Department of Pediatrics

The First Affiliated Hospital of Xi'an Jiaotong University No. 277 Healthy West Road $X i$ 'an 710061

China

E-mail: shiruiming56@163.com

Received 9 October 2019/Accepted 20 November 2019 